\title{
PENINGKATAN EFISIENSI DAN EFEKTIVITAS OPERASIONAL NELAYAN PADA PANTAI YANG CURAM DENGAN ALAT PEMINDAH PERAHU
}

\author{
IGN Adi Tanaya ${ }^{1}$, I Made Suartika, ST., MT ${ }^{2}$, IDK Okariawan, ST., MT ${ }^{3}$ \\ Jurusan Mesin Fakultas Teknik Universitas Mataram \\ Jl. Majapahit No 62 Mataram, Nusa Tenggara Barat
}

\begin{abstract}
Indonesia is known as an archipelago that has abundant marine resources, this should make Indonesia a wealthy and prosperous country. Unfortunately, these resources cannot be fully utilized because there is still a lack of support for technology and human resources in an effort to explore the existing marine resources. It is no wonder then many coastal communities are middle to lower living standards. Most of the fishermen have to pay people to help the process of shifting their boat, especially the fishermen on the steep coast so that it can reduce their revenue.

This research aims to improve the operational productivity of fishermen on the steep coast by using an alternative concept, so that it reduces human labor as shifting assistant in the traditional shifting. Three alternative concepts has been designed to assist those shifting process, ie Tripod, Boat Train, and Boat Wheel. The designs was then selected to obtain the best concept. Concept selection was using the matrix assessment Analitycal Hierarchy Process (AHP) by assistance of data processing using Expert Choise 11 program furthermore method followed by using Pugh method to compare the boat shifting process between alternative concept and traditional shifting.

Concept selection gives certain point for each concept, Tripod 0.3044 point, Boat Train 0.3998 point, and Boat Wheel 0.4385 point. It shows that boat wheel design selected as the best alternative concept. The comparison of total productivity between the best alternative concept and traditional shifting is 2.32 to 1.66 . It means boat shifting process by using alternative concept design can be increase productivity counting $28 \%$.
\end{abstract}

Key Word : Productivity, Concept selection, Analitycal Hierarchy Process (AHP), Fishermen of the Steep Coast.

\section{PENDAHULUAN}

Indonesia dikenal sebagai Negara Bahari karena Indonesia merupakan negara kepulauan dengan wilayah panjang pantai lebih dari $81.000 \mathrm{~km}$, Indonesia memiliki 17.504 pulau-pulau kecil yang tersebar di seluruh wilayah Indonesia, selain pulau-pulau besar yang telah dikenal sebelumnya. Hal inilah yang menjadikan Indonesia disebut sebagai Negara Kepulauan. Potensi Kelautan Indonesia yang besar telah memberikan sumbangan devisa sebesar US \$2,6 miliar (2008). Jumlah tersebut lebih baik dari tahun 2007 yang hanya US \$2,3 miliar saja. Potensi kelautan dan perikanan Indonesia mencapai 70 persen dari wilayah NKRI secara keseluruhan (Putera, 2009) ${ }^{[1]}$.

Menyebut "Nelayan" khususnya nelayan tradisional, orang akan selalu menghubungkannya dengan kehidupan yang serba susah, hidup pas-pasan. Ini merupakan gambaran yang diberikan oleh orang untuk menggambarkan betapa miskinnya kehidupan nelayan tradisional. Secara realitas, memang kondisi kehidupan nelayan khususnya nelayan tradisional memang miskin. Sangat disayangkan dengan potensi pesisir dan laut Indonesia yang begitu besar dimana laut Indonesia termasuk yang paling luas di dunia namun tidak dimanfaatkan secara maksimal (Dahuri, 2005) [2]

\section{TINJAUAN PUSTAKA}

\subsection{Konsep Dasar Produktifitas}

Pada tahun 1883, Litter mendefinisikan produktivitas sebagai kemampuan untuk berproduksi. Kemudian pada awal abad ke 19 dikenal definisi yang lebih spesifik yang menyatakan bahwa produktivitas merupakan hubungan antara keluaran dan sumber yang digunakan untuk menghasilkan keluaran tersebut.

Apabila ukuran keberhasilan produksi hanya dipandang dari satu sisi, maka produktivitas dipandang dari dua sisi sekaligus, yaitu: sisi input dan sisi output. Dengan demikian dapat dikatakan bahwa produktivitas berkaitan dengan efisiensi penggunaan input dalam memproduksi output barang atau jasa (Suhartati, 2005) ${ }^{[3]}$.

Siklus produktifitas bukanlah suatu proyek yang hanya sekali berjalan, tetapi merupakan siklus yang kontinyu, proses yang berlangsung berkesinambungan. Siklus produktivitas merupakan suatu daur yang mencakup empat tahap, seperti pada gambar berikut : 


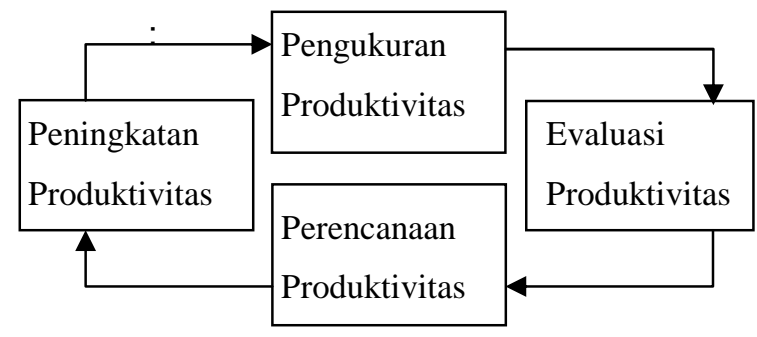

Gambar 1 Siklus Produktivitas

(Sumber : Sumanth, 1985) ${ }^{[4]}$

\subsection{Seleksi Konsep}

Menurut Ulrich dan Eppinger (2001) ${ }^{[5]}$, seleksi konsep merupakan proses menilai konsep dengan memperhatikan kebutuhan pelanggan dan kriteria lain, membandingkan kekuatan dan kelemahan relatif dari konsep dan memilih satu atau lebih konsep untuk penyelidikan, pengujian dan pengembangan selanjutnya. Beberapa metode seleksi konsep yaitu:

- Kebutuhan eksternal

- Produk juara

- Intuisi

- Multivoting

- Pro dan kontra

- Prototipe dan pengujian, dan

- Matrik keputusan

\subsection{AHP ( Analitycal Hierarchy Process )}

Menurut Syaifullah $(2010)^{[6]}$, AHP merupakan suatu model pendukung keputusan yang dikembangkan oleh Thomas L. Saaty. Model pendukung keputusan ini akan menguraikan masalah multi faktor atau multi kriteria yang kompleks menjadi suatu hirarki, menurut Saaty (1993), hirarki didefinisikan sebagai suatu representasi dari sebuah permasalahan yang kompleks dalam suatu struktur multi level dimana level pertama adalah tujuan, yang diikuti level faktor, kriteria, sub kriteria, dan seterusnya ke bawah hingga level terakhir dari alternatif.

Menurut Wahyuningsih $(2002)^{[7]}$, Model AHP menggunakan manusia yang dianggap "Expert" sebagai input utamanya. Karena menggunakan input yang kualitatif (persepsi manusia) maka model ini dapat mengolah juga hal-hal kualitatif disamping hal-hal kuantitatif.

Hasil perbandingan dari masing-masing elemen akan berupa angka dari 1 sampai 9 yang menunjukkan perbandingan tingkat kepentingan suatu elemen. Apabila suatu elemen dalam matriks dibandingkan dengan dirinya sendiri maka hasil perbandingan diberi nilai 1.

Skala perbandingan berpasangan diperkenalkan oleh Saaty seperti pada tabel berikut:
Tabel 1 Skala perbandingan

\begin{tabular}{|c|l|}
\hline $\begin{array}{c}\text { Nilai } \\
\text { Skala }\end{array}$ & \multicolumn{1}{|c|}{ Definisi } \\
\hline 1 & Kedua elemen sama penting \\
\hline 3 & $\begin{array}{l}\text { Elemen yang satu sedikit lebih } \\
\text { penting dari yang lainnya }\end{array}$ \\
\hline 5 & $\begin{array}{l}\text { Elemen yang satu sesungguhnya } \\
\text { lebih penting dari elemen yang } \\
\text { lainya }\end{array}$ \\
\hline 7 & $\begin{array}{l}\text { Satu elemen jelas lebih penting dari } \\
\text { yang lainnya mutlak lebih penting }\end{array}$ \\
\hline 9 & $\begin{array}{l}\text { Satu elemen muta kedua } \\
\text { dari elemen lainnya }\end{array}$ \\
\hline $2,4,6,8$ & $\begin{array}{l}\text { Nilai tengah diantara } \\
\text { pertimbangan yang berdekatan }\end{array}$ \\
\hline
\end{tabular}

\subsection{Perangkat lunak Expert Choice}

Menurut Sultan (2009) ${ }^{[8]}$, Expert Choice adalah sebuah aplikasi yang khusus digunakan sebagai alat bantu implementasi model-model dalam Decission Support System (DSS) atau yang lebih dikenal dengan sebutan Sistem Penunjang Keputusan (SPK) dalam sebuah perusahaan ataupun untuk keperluan akademik (PBM).

Perangkat lunak Expert Choice (EC) adalah alat bantu untuk menentukan prioritas sebuah keputusan multi-kriteria berdasarkan metode Analitycal Hierarchy Process (AHP), sebuah teori matematika yang pertama dikembangkan di Wharton School of the University of Pennsylvania oleh salah satu orang pendiri Expert Choice, Thomas L. Saaty (Kurniawan, 2009) ${ }^{[9]}$.

\section{METODE PENELITIAN}

Adapun metode yang akan digunakan dalam penelitian ini adalah metode deskriptif dengan studi kasus di beberapa pantai yang memiliki topologi pantai yang curam di kawasan pantai Ampenan, Melase, dan Meninting Kabupaten Lombok Barat NTB dengan langkahlangkah penelitian sebagai berikut: 


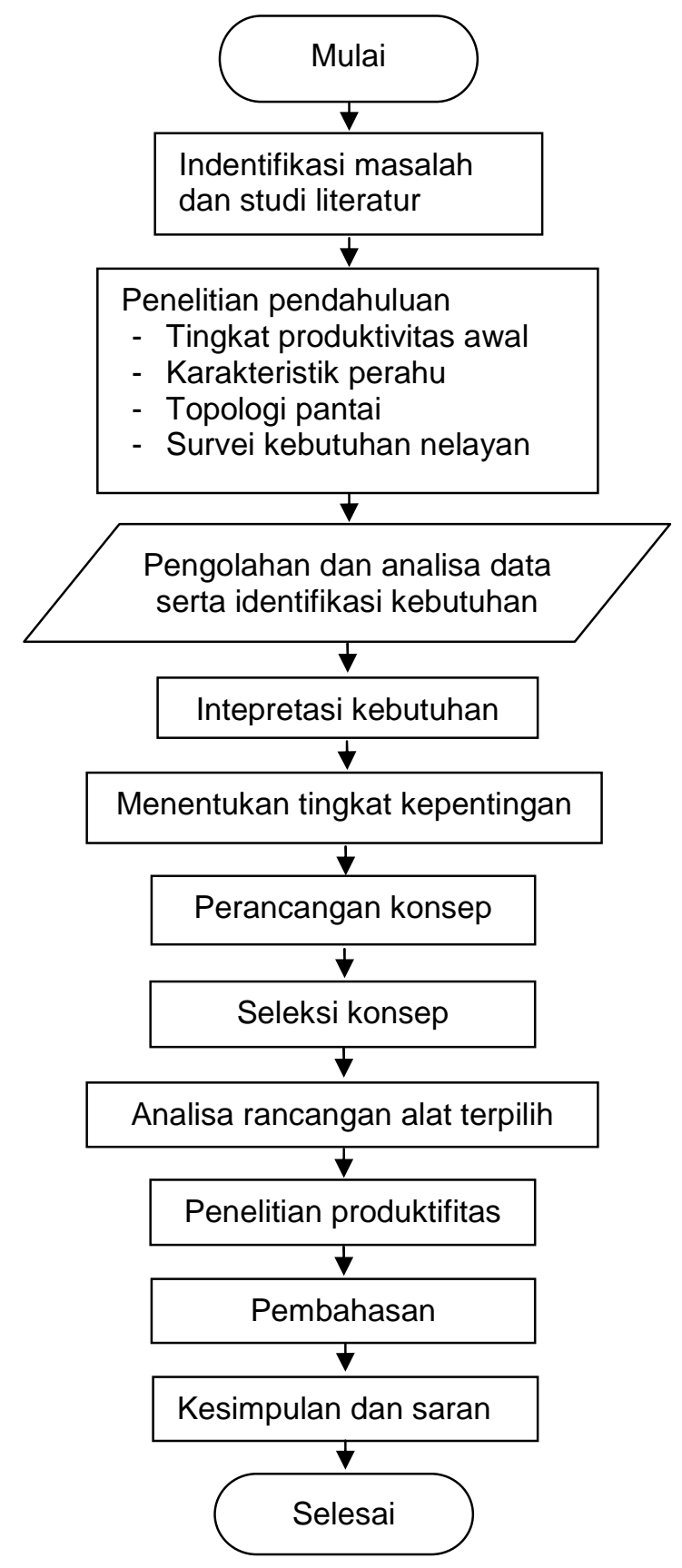

Gambar 2 Langkah-langkah penelitian

\section{ANALISA DAN PEMBAHASAN}

\subsection{Survei Indentifikasi Masalah}

Hasil observasi produktifitas nelayan dipantai yang curam dikawasan pantai Ampenan, Meninting dan Melase Kabupaten Lombok Barat, NTB selama 1 minggu dari tanggal 5-11 maret 2012 bahwa produktifitas nelayan masih sangat kurang yaitu hanya 0.78 masih jauh dari angka 1 sebagai zero point (titik nol produktifitas).

Banyak faktor yang menyebabkan hal demikian seperti yang disampaikan beberapa responden (nelayan) yaitu faktor cuaca, ikan yang berkelompok yang berenang terlalu jauh ketengah laut sehingga membutuhkan banyak biaya untuk membeli minyak perahu sedangkan tidak adanya kepastian hasil yang didapat, serta pengeluaran biaya saat pemindahan perahu yaitu pembayaran tenaga pembantu dalam pemindahan perahu dari laut menuju ke pantai tempat biasanya nelayan menyimpan perahunya.

Dari beberapa faktor yang disebutkan diatas faktor ketiga merupakan fokus pembahasan yaitu peningkatan produktifitas pada aktifitas pemindahan perahu di kondisi pantai yang curam karena pada tradisi masyarakat nelayan sekarang, bahwa nelayan harus memberikan upah kepada tenaga pembantu pemindahan baik berupa ikan hasil tangkapan atau dalam bentuk uang sehingga dapat mengurangi hasil melaut.

\subsection{Hasil Penelitian Pendahuluan}

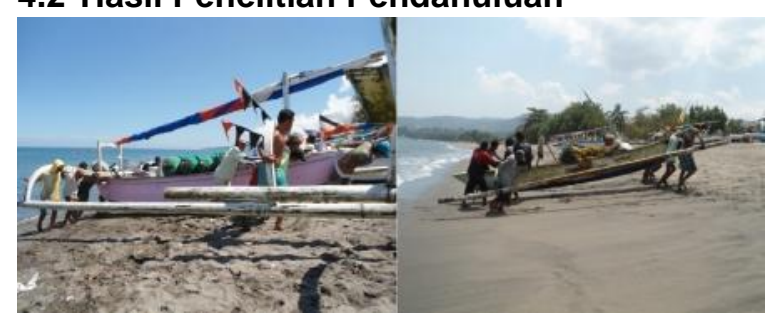

Gambar 3 Dokumentasi Hasil Survei Pemindahan Perahu Cara Tradisional (Sumber : Pantai Ampenan dan pantai Melase, Lombok Barat NTB)

Gambar diatas merupakan hasil observasi realita aktifitas pemindahan perahu dari laut menuju kepantai dengan cara tradisional atau diangkat manual dengan cara dipikul, menggunakan tenaga manusia dengan beberapa orang tenaga pembantu. Hasil survei data analisa terhadap 30 responden menjelaskan bahwa nelayan yang ingin memindahkan perahunya dipantai sehabis melaut rata-rata membutuhkan 12 orang tenaga pembantu dengan upah Rp 9.000,-/orang, bila ditotalkan maka pengeluaran nelayan untuk membayar tenaga pembantu sebanyak $R p$ 106.000,- dalam sekali melaut dengan rata-rata penghasilan yang didapat adalah Rp 559.167,dengan besar modal rata-rata yang digunakan sebesar 222.367,-.. Jika dilihat dari segi topografi atau kemiringan sudut pantai, peneliti mengambil beberapa titik pantai curam yang berada di 3 kawasan pantai tersebut. Hasil pengukuran kemiringan pantai didapatkan bahwa rata-rata kemiringan ke-3 pantai tersebut adalah 13,29을 , berdasarkan kriteria kecuraman pantai yang disampaikan oleh kepala pusat penyuluhan kelautan dan perikanan $(2011)^{[10]}$ maka pantai tersebut tergolong pantai yang curam. 


\subsection{Identifikasi Kebutuhan Nelayan}

Permasalahan yang rata-rata nelayan mengeluhkan hal yang sama sehingga pengelompokkan permasalahan tersebut terlihat pada tabel berikut :

Tabel 2 Identifikasi Kebutahan Nelayan

\begin{tabular}{|c|c|}
\hline $\begin{array}{l}\text { Hasil } \\
\text { Survei } \\
\end{array}$ & Jawaban \\
\hline $\begin{array}{l}\text { Kendala yang } \\
\text { dialami }\end{array}$ & $\begin{array}{l}\text { 1. Pegal pada pundak dan kaki } \\
\text { 2. Proses angkat perahu mahal } \\
\text { 3. Kecuraman pantai } \\
\text { mempengaruhi jumlah tenaga } \\
\text { pembantu. } \\
\text { 4. Jauhnya jarak posisi } \\
\text { pemindahan dari garis } \\
\text { pasang tertinggi air laut } \\
\text { membuat badan cepat lelah. }\end{array}$ \\
\hline $\begin{array}{l}\text { Kekurangan } \\
\text { proses } \\
\text { pemindahan } \\
\text { perahu cara } \\
\text { tradisional }\end{array}$ & $\begin{array}{l}\text { 1. Tidak ada tenaga pembantu, } \\
\text { proses pemindahan tidak } \\
\text { berjalan } \\
\text { 2. Mengeluarkan biaya setiap } \\
\text { melakukan aktifitas } \\
\text { pemindahan perahu. }\end{array}$ \\
\hline
\end{tabular}

\subsection{Intepretasi Kebutuhan}

Dari hasil identifikasi diatas maka dapat di intepretasikan beberapa kebutuhan nelayan pada proses pemindahan yaitu proses pemindahan yang menggunakan alat atu tidak lagi menggunakan tenaga manusia atau tenaga manusia hanya sebagai fasilitas (operator).

\subsection{Menentukan Tingkat Kepentingan Kebutuhan}

Setelah dilakukan intepretasi kebutuhan nelayan, data tersebut digunakan untuk mengidentifikasi tingkat kebutuhan nelayan terhadap sebuah alat pemindahan perahu (tingkat kepentingan), dimana hasil interpretasi kebutuhan tersebut didapat dari nelayan dan digunakan sebagai pedoman kebutuhan pelanggan (costumer need) dalam penilaian konsep. Adapun hasil survei tingkat kepentingan kebutuhan nelayan sebagai berikut:

Tabel 3 Intepretasi dan tingkat kepentingan kebutuhan nelayan

\begin{tabular}{|l|l|c|}
\hline No & \multicolumn{1}{|c|}{ Kebutuhan } & $\begin{array}{c}\text { Tingkat } \\
\text { kepentingan }\end{array}$ \\
\hline $\mathbf{1}$ & Biaya produksi murah & 5 \\
\hline 2 & Mengurangi tenaga pembantu & 5 \\
\hline 3 & $\begin{array}{l}\text { Tidak mengganggu kesehatan } \\
\text { nelayan }\end{array}$ & 5 \\
\hline 4 & $\begin{array}{l}\text { Tidak menghabiskan banyak } \\
\text { tenaga }\end{array}$ & 3 \\
\hline 5 & $\begin{array}{l}\text { Tidak ada pengeluaran biaya } \\
\text { dalam proses pemindahan }\end{array}$ & 4 \\
\hline 6 & $\begin{array}{l}\text { Kecuraman pantai tidak } \\
\text { mempengaruhi biaya }\end{array}$ \\
\hline
\end{tabular}

\begin{tabular}{|l|l|c|}
\hline 7 & $\begin{array}{l}\text { Jauhnya Jarak perpindahan } \\
\text { tidak membuat badan lelah }\end{array}$ & 4 \\
\hline 8 & Mudah perawatan & 3 \\
\hline 9 & Ergonomis & 4 \\
\hline 10 & $\begin{array}{l}\text { Bisa disimpan dimana saja } \\
\text { saat tidak digunakan }\end{array}$ & 3 \\
\hline 11 & Mudah dipindah-pindahkan & 2 \\
\hline 12 & $\begin{array}{l}\text { Panjang umur penggunaan } \\
\text { alat }\end{array}$ & 2 \\
\hline 13 & Mudah saat instalasi & 3 \\
\hline 14 & $\begin{array}{l}\text { Tahan panas matahari dan air } \\
\text { laut }\end{array}$ & 2 \\
\hline 15 & Mudah dibersihkan & 3 \\
\hline
\end{tabular}

\subsection{Perancangan Konsep}

Konsep produk merupakan gambaran secara ringkas bagaimana produk yang dibuat dapat memuaskan akan kebutuhan yang diharapkan oleh pelanggan. Sehingga konsep produk dapat diartikan sebagai perkiraan prinsip kerja dan bentuk produk. Berikut adalah beberapa konsep alternatif alat pemindahan perahu.

a. Konsep alternatif alat 1

\section{Gambar 4 Tripod}

b. Konsep alternatif alat 2

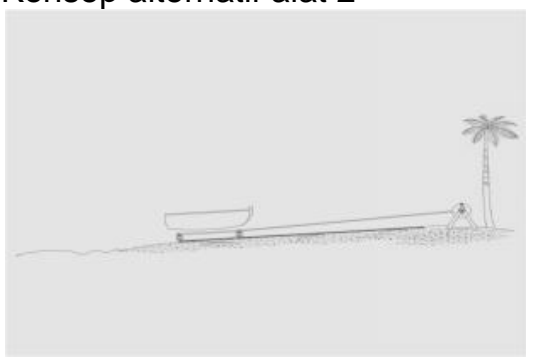

Gambar 5 Kereta perahu

c. Konsep alternatif alat 3

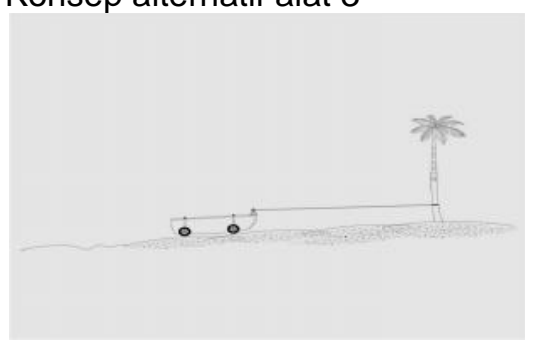

Gambar 6 Roda perahu 


\subsection{Seleksi Konsep}

Seleksi konsep dilakukan 2 tahap, tahap pertama penyaringan alternatif konsep alat menggunakan matrik penilaian. Pemberi keputusan dilakukan oleh tim ahli menggunakan metode AHP (Analitycal Hierarchy Process) dengan perhitungan dari perangkat lunak Expert Choice 11 kemudian data yang didapat di Input ke tabel matrik penilaian tahap pertama.

Tabel 4 Hasil Seleksi Konsep Tahap Pertama dengan Matrik Penilaian

\begin{tabular}{|c|c|c|c|c|c|c|c|c|}
\hline \multirow[b]{2}{*}{ No } & \multirow[b]{2}{*}{ Kriteria } & \multirow[b]{2}{*}{ Bobot } & \multicolumn{2}{|c|}{ Alternatif 1} & \multicolumn{2}{|c|}{ Alternatif 2} & \multicolumn{2}{|c|}{ Alternatif 3} \\
\hline & & & Nilai & $\begin{array}{l}\text { Nilai } x \\
\text { Bobot }\end{array}$ & Nilai & $\begin{array}{l}\text { Nilai } x \\
\text { Bobot }\end{array}$ & Nilai & $\begin{array}{l}\text { Nilai } x \\
\text { Bobot }\end{array}$ \\
\hline \multirow[t]{8}{*}{ A. } & Manufaktur & 0,416 & & & & & & \\
\hline & 1. Biaya produksi murah & 0,036 & 0,6496 & 0,0234 & 0,2142 & 0,0077 & 0,1182 & 0,0043 \\
\hline & 2. Harga spare part murah & 0,053 & 0,2632 & 0,0141 & 0,5418 & 0,0289 & 0,1954 & 0,0104 \\
\hline & 3. Lama umur pemakaian alat & 0,034 & 0,2782 & 0,0095 & 0,2046 & 0,0070 & 0,517 & 0,0176 \\
\hline & 4. Lamanya penggantian spare part & 0,040 & 0,3642 & 0,0145 & 0,1846 & 0,0073 & 0,4514 & 0,0180 \\
\hline & 5. Spare part mudah dicari & 0,124 & 0,1476 & 0,0182 & 0,5186 & 0,0641 & 0,3338 & 0,0413 \\
\hline & 6. Jumlah tahapan perakitan sedikit & 0,022 & 0,5232 & 0,0114 & 0,2306 & 0,0050 & 0,3522 & 0,0077 \\
\hline & $\begin{array}{l}\text { 7. Kerusakan komponen karena pengaruh } \\
\text { lingkungan }\end{array}$ & 0,108 & 0,2658 & 0,0287 & 0,6054 & 0,0653 & 0,129 & 0,0139 \\
\hline \multirow[t]{6}{*}{ B. } & Fleksibilitas penggunaan & 0,380 & & & & & & \\
\hline & $\begin{array}{l}\text { 1. Dapat digunakan pada lokasi pantai yang } \\
\text { berbeda-beda }\end{array}$ & 0,067 & 0,2562 & 0,0171 & 0,1786 & 0,0119 & 0,5652 & 0,0378 \\
\hline & 2. Mudah dipindah-pindahkan & 0,070 & 0,3644 & 0,0254 & 0,1006 & 0,0070 & 0,5348 & 0,0373 \\
\hline & 3. Ergonomis & 0,088 & 0,2064 & 0,0181 & 0,2522 & 0,0221 & 0,5416 & 0,0474 \\
\hline & $\begin{array}{l}\text { 4. Sedikit membutuhkan tenaga pembantu dalam } \\
\text { operasi }\end{array}$ & 0,097 & 0,3256 & 0,0316 & 0,1036 & 0,0100 & 0,571 & 0,0554 \\
\hline & 5. Mudah saat instalasi & 0,058 & 0,2526 & 0,0147 & 0,1322 & 0,0077 & 0,6148 & 0,0357 \\
\hline \multirow[t]{4}{*}{ C. } & Perawatan & 0,158 & & & & & & \\
\hline & 1. Mudah dibersihkan & 0,031 & 0,2858 & 0,0089 & 0,1666 & 0,0052 & 0,567 & 0,0177 \\
\hline & 2. Spare part mudah dibongkar pasang. & 0,074 & 0,3538 & 0,0260 & 0,387 & 0,0285 & 0,2592 & 0,0191 \\
\hline & 3. Bisa disimpan dimana saja saat tidak digunakan & 0,049 & 0,25 & 0,0124 & 0,1936 & 0,0096 & 0,4392 & 0,0217 \\
\hline \multirow[t]{3}{*}{$\mathrm{D}$} & Aspek lingkungan & 0,196 & & & & & & \\
\hline & 1. Ketahanan korosi akibat air laut & 0,141 & 0,1432 & 0,0201 & 0,673 & 0,0946 & 0,1842 & 0,0259 \\
\hline & 2. Tahan panas matahari dan air laut & 0,056 & 0,187 & 0,0104 & 0,32 & 0,0179 & 0,4928 & 0,0275 \\
\hline \multicolumn{3}{|c|}{ Total Nilai } & & 0,3044 & & 0,3998 & & 0,4385 \\
\hline \multicolumn{3}{|c|}{ Ranking } & & & & & & \\
\hline
\end{tabular}

Konsep yang memiliki ranking pertama adalah konsep alternatif 3 yaitu roda perahu dengan total nilai 0,4385 sehingga dapat disimpulkan konsep tersebut adalah konsep yang terbaik. Selanjutnya konsep ini yang nantinya akan dianalisa rancangnya. Kemudian tahap kedua yaitu seleksi konsep untuk menguji apakah konsep tersebut lebih baik dari proses pemindahan perahu dengan cara tradisional.

Berikut adalah hasil analisa penilaian metode pemindahan perahu cara tradisional dengan menggunakan alternatif rancangan konsep alat pemindah perahu:

Tabel 5 Seleksi tahap ke-2

\begin{tabular}{|l|c|c|}
\hline \multicolumn{1}{|c|}{ Kriteria } & Roda Perahu & Tradisional \\
\hline Kemudahan penggunaan & + & - \\
Kemudahan penanganan & + & - \\
Hemat biaya & + & - \\
Fleksibilitas penggunaan & + & - \\
Kenyamanan penggunaan & + & - \\
\hline Jumlah (+) & 5 & 0 \\
Jumlah (0) & 0 & 0 \\
Jumlah (-) & 0 & 5 \\
\hline Nilai bersih & 5 & -5 \\
Ranking & 1 & 2 \\
\hline
\end{tabular}

Dari hasil penilaian konsep diatas, dapat dilihat bahwa konsep pemindahan dengan alternative alat lebih unggul dari pada konsep pemindahan tradisonal, maka konsep pemindahan perahu dengan alternative alat Roda perahu keluar sebagai konsep akhir yang terbaik dari aktifitas pemindahan perahu dipantai yang curam.

\subsection{Rancangan Alat Pemindah Perahu}

Berikut adalah konsep rancangan alternatif alat pemindah perahu yang terpilih sebagai konsep alternatif alat yang terbaik hasil seleksi konsep oleh para ahli.

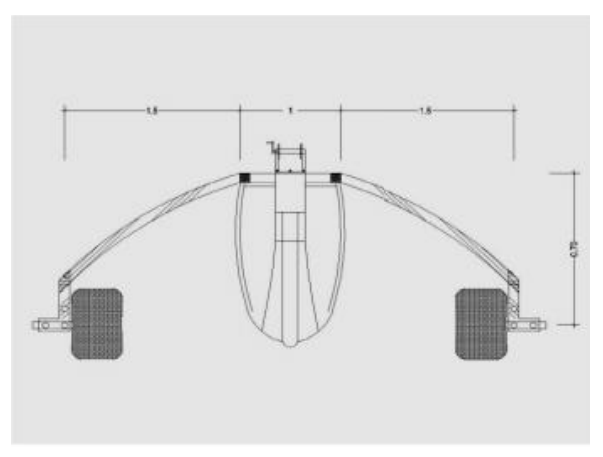

Gambar 7 Roda perahu saat digunakan di darat 


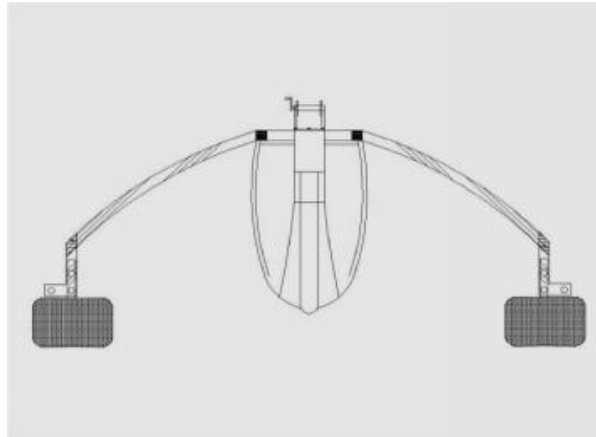

Gambar 8 Roda perahu saat digunakan di laut

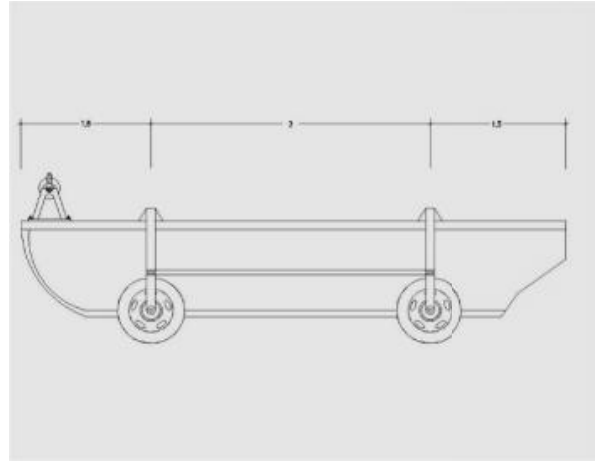

Gambar 9 Roda perahu tampak samping

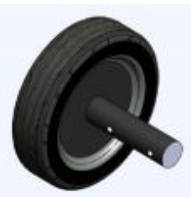

Gambar 10 Desain Batang poros pada roda

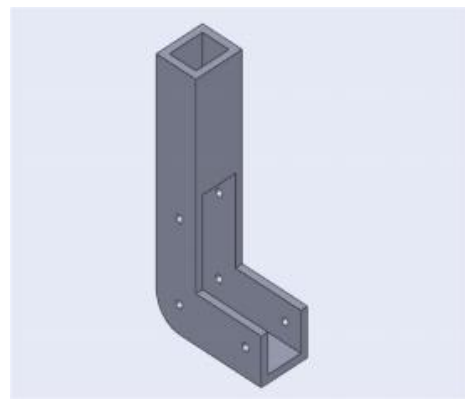

Gambar 11 Batang L Lock

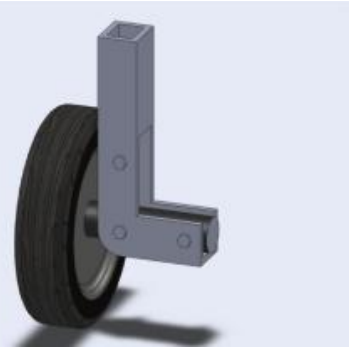

Gambar 12 Desain roda dipantai Pandangan 3D

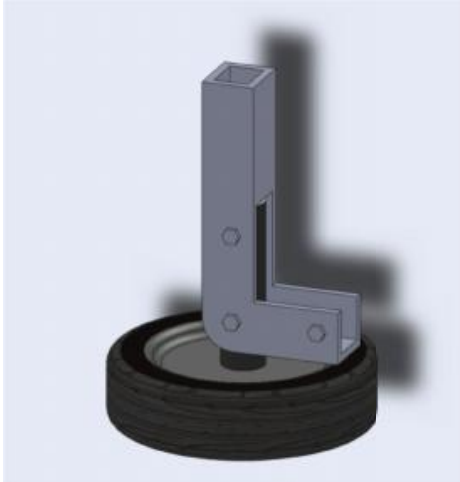

Gambar 13 Desain roda sebagai kantir pandangan 3D

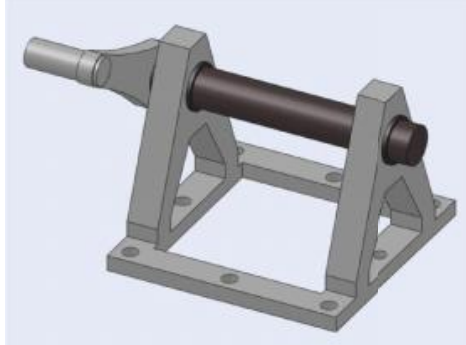

Gambar 14 Penggulung tali pandangan 3D

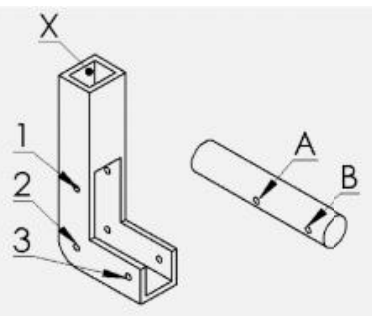

Gambar 15 Instalasi batang L lock dengan poros roda

\subsection{Penelitian Produktifitas}

Untuk mengetahui tingkat produktifitas pada aktifitas pemindahan perahu nelayan dapat dianalisa dari pengukuran produktifitas proses pemindahan dengan cara tradisional dan pengukuran produktifitas dengan menggunakan alternatif alat pemindah perahu, model pengukuran produktifitas dapat menggunakan model pengukuran produktifitas oleh Daviu' J! Sumanth sebagai berikut :

Produktivitas total $=\frac{\text { Nilai keluaran total }(\text { tangible })}{\text { Nilai masukan total (tangible) }}$

dimana :

a. Nilai keluaran total $=($ nilai produk jadi + nilai produk setengah jadi + deviden bunga

Pinjaman + pendapatan lainnya) pada periode tersebut.

b. Nilai masukan total = (masukan tenaga kerja + masukan bahan baku + masukan modal + 
masukan energi + pengeluaran lainnya) pada periode tersebut.

Untuk dapat menjawab produktifitas awal dan produktifitas akhir maka kita dapat melihat dari hasil survei awal dan akhir yang didapat dengan kondisi bahwa kedua pengukuran diasumsikan sama:

- Diketahui data survei pemindahan perahu cara tradisional :

1. Rata-rata modal melaut $\mathrm{Rp} 222.367,-$

2. Rata-rata penghasilan melaut yang didapat Rp 559.167,-

3. Upah yang diberikan kepada tenaga pembantu Rp 9.000,- /orang

4. Jumlah tenaga pembantu 12 orang

$$
\begin{aligned}
\text { Produktivitas total } & =\frac{\text { Penghasilan melaut }}{(\text { modal }+ \text { upah tenaga pembantu })} \\
& =\frac{559.167}{222.367+(12 \times 9.000)}=1,66
\end{aligned}
$$

- Diketahui hasil analisa menggunakan alat pemindah perahu

1. Rata-rata modal melaut $\mathrm{Rp} 222.367$,-

2. Rata-rata penghasilan melaut yang didapat Rp 559.167,-

3. Upah yang diberikan kepada tenaga pembantu Rp 9.000,-/orang

4. Jumlah tenaga pembantu 2 orang

$$
\begin{aligned}
\text { Produktivitas total } & =\frac{\text { Penghasilan melaut }}{(\text { modal }+ \text { upah tenaga pembantu })} \\
& =\frac{559.167}{222.367+(2 \times 9.000)}=2.32
\end{aligned}
$$

\subsection{Pembahasan}

Data diatas merupakan jawaban bahwa proses pemindahan perahu dari laut kepantai dan sebaliknya, menggunakan konsep alternatif alat pemindah perahu yaitu Roda Perahu merupakan alternatif yang terbaik pada aktifitas pemindahan perahu nelayan dibandingkan alternatif konsep lainnya. Serta alternatif konsep ini juga memiliki nilai produktifitas lebih tinggi dibandingkan dengan pemindahan perahu cara tradisional karena alternatif tersebut dapat mengurangi jumlah tenaga pembantu sehingga dapat mereduksi banyak biaya input dan nelayan dapat bekerja lebih efektif dan efisien. Sesua teori peningkatan produktifitas yaitu "Output konstan sedangkan input mengalami penurunan". Artinya tidak melakukan penambahan output, melainkan input yang digunakan dengan lebih hemat dan berusaha untuk mengurangi pemborosan/pengeluaran biaya dengan bekerja lebih efektif dalam menghasilkan output atau biaya yang dikeluarkan diusahakan serendah mungkin.
Dengan berkurangnya pengeluaran biaya untuk tenaga pembantu sehingga keuntungan hasil melaut dapat dinikmati oleh nelayan itu sendiri dalam mencukupi kebutuhan hidupnya.

\section{Kesimpulan}

Berdasarkan analisis dan evaluasi yang dilakukan untuk peningkatan efisiensi dan efektivitas operasional nelayan pada pantai yang curam dengan menggunakan alat pemindah perahu maka dapat disimpulkan beberapa hal sebagai berikut :

a. Dari hasil seleksi konsep, rancangan alternatif alat yang keluar sebagai konsep terbaik yang dapat meningkatkan efisiensi dan efektifitas operasional nelayan dalam pemindahan perahu pada pantai yang curam adalah alternatif rancangan alat Roda Perahu yang didapatkan dari pengolahan Expert choise 11 dengan tim ahli sebagai pemberi keputusan alternatif ini mendapatkan nilai bobot sebesar 0,4385.

b. Dari hasil pengolahan AHP dengan perangkat lunak Expert choise didapat kriteria alat pemindah perahu yang memiliki bobot kepentingan paling besar berturutturut adalah manufaktur, fleksibilitas penggunaan, aspek lingkungan dan yang terakhir adalah perawatan.

c. Berdasarkan hasil seleksi konsep Pugh pada uji pemilihan metode pemindahan perahu dari beberapa kriteria diketahui bahwa Pemindahan perahu dengan alternatif rancangan alat merupakan konsep pemindahan terbaik dibandingkan dengan pemindahan cara tradisonal.

d. Berdasarkan hasil uji produktivitas diketahui bahwa ada peningkatan produktifitas operasional nelayan dilihat dari nilai produktifitas pemindah perahu cara tradisional yaitu 1,66 menjadi 2,32 dengan bantuan rancangan alat pemindah perahu

\section{Daftar Pustaka}

[1] Putera, P.B., 2009, "Teknologi Informasi untuk Kelautan Indonesia", LIPI, Indonesia.

[2] Dahuri, R., 2005, "Mengembalikan Kejayaan Negeri Bahari" rokhmindahuri.wordpress.com, Tanggal download 23-10-2011.

[3] Suhartati, 2005, "Analisis Pengukuran Tingkat Produktivitas Secara Parsial Menggunakan Model Pospac Di PT. Indofood Sukses Makmur Tbk" Tugas Akhir, Universitas Komputer Indonesia, Bandung. 
[4] Sumanth, D.J., 1985, "Productivity Engineering And Management", McGrawHill Book Company, New York.

[6] Syaifullah, 2010, "Pengenalan Metode AHP (Analytical Hierarchy Process )" Syaifullah08.Wordpress.Com

[7] Wahyuningsih, E.D.S., 2002, "Perancangan Sistem Pengukuran Performasi Organisasi Dengan Metode Integrated Performace Measurements Systems (studi kasus: Badan Perencanaan Pembangunan Propinsi Jawa Timur" Program Pascasarjana, Institut Teknologi Sepuluh Nopember, Surabaya.
[8] Sultan, 2009, "Experts Choice 11 tutorial" http://ekofiles.darmajaya.ac.id/, Tanggal download 25-04-2012.

[9] Kurniawan, Y.A., 2009, "Sistem Penunjang Keputusan Dalam Penentuan Prioritas Pemilihan Proyek Transmisi SDH Menggunakan Metode AHP \& Expert Choice (studi kasus: PT. ZTE Indonesia)", Tesis, Universitas Indonesia, Jakarta.

[10] Kepala Pusat Penyuluhan Kelautan dan Perikanan., 2011, "Konservasi Biota Terancam Punah.Pdf". http://pusluh.kkp.go.id, Tanggal download 28-2-2012. 